Meta

Journal des tradlucteurs

Translators' Journal

\title{
Guidère, Matthieu (2000) : Publicité et traduction. Paris :
}

L'Harmattan, $320 \mathrm{p}$.

\section{Francis Guinle}

Volume 47, numéro 3, septembre 2002

URI : https://id.erudit.org/iderudit/008025ar

DOI : https://doi.org/10.7202/008025ar

Aller au sommaire du numéro

Éditeur(s)

Les Presses de l'Université de Montréal

ISSN

0026-0452 (imprimé)

1492-1421 (numérique)

Découvrir la revue

Citer ce compte rendu

Guinle, F. (2002). Compte rendu de [Guidère, Matthieu (2000) : Publicité et

traduction. Paris : L’Harmattan, 320 p.] Meta, 47(3), 432-435.

https://doi.org/10.7202/008025ar

Ce document est protégé par la loi sur le droit d'auteur. L'utilisation des services d'Érudit (y compris la reproduction) est assujettie à sa politique d'utilisation que vous pouvez consulter en ligne.

https://apropos.erudit.org/fr/usagers/politique-dutilisation/
Cet article est diffusé et préservé par Érudit.

Érudit est un consortium interuniversitaire sans but lucratif composé de l'Université de Montréal, l'Université Laval et l'Université du Québec à Montréal. Il a pour mission la promotion et la valorisation de la recherche. https://www.erudit.org/fr/ 


\section{Comptes rendus}

Guidère, Matthieu (2000): Publicité et traduction. Paris: L’Harmattan, 320 p.

As the title indicates, this work aims at describing the interactions between advertising and translation at the time of globalism. In fact, it concerns the international advertising of multinational firms which increasingly need to translate their communication campaigns simultaneously into several languages. ${ }^{1}$ The commercials and advertisements analysed are borrowed from the French language and compared with their English, Arabic, Portuguese and Spanish versions. But other examples are quoted for information in the appendix. ${ }^{2}$

In the first part, entitled "Theoretical Framework," the author briefly outlines the influential parameters in the field of advertising translation and gives some basic definitions in the science of translation before launching into in-depth analysis of the type of equivalence required in advertising and of the method which makes it possible to hit on "the beautiful and effective ones" in order to translate the stylistic effects of the original message and make sense of it. ${ }^{3}$

The main body of the work hinges on two chapters respectively entitled "Advertising Verbal Text and Translation," and "Advertising Image and Translation.” In the first, the argument is built around three major features of the advertising message, namely the trademark, the catch phrase, and the advertorial. After having analysed the various possible ways of rendering the names (the name of the product and the name of the brand) and the catch phrases (the catch line and the back-up line), the author turns his attention to the types of texts the translator is likely to come across in the advertisements of international advertising. He studies the various procedures which make it possible to impart the specificity of the text of origin, quoting precise examples. ${ }^{4}$ At this stage, two concepts make it possible to determine the communication practices of the multinationals: the "advertising multitext" which refers to the various original versions of the same source message, and the "multitranslation" which refers to the possible and necessary readjustments of the original message under process.

In a second phase, we are presented with the main "adaptations" which can be assigned to the advertising image when switching from one language to another. The author expounds, one after the other, the rules which control the transfer of the advertising object, character and framework. He then carries out a thorough analysis of the links which connect the text and the image within the commercial communication and which the translator cannot ignore without running the risk of producing an inefficient and inconsistent translation. ${ }^{5}$

The last part of the work, entitled "Advertising Culture and Translation" makes it possible to grasp the cultural scope of advertising translation at the time of global economy, and to become aware of the cultural stakes of this type of standardized communication. ${ }^{6}$ The author insists on the standardization which can result from 
such a translation practice. He expounds the aspects of the advertising transfer which seem to him worthy of interest under a heading with the significant title: "Uniculture" (III.1.3.). These aspects are put into perspective in the conclusion which calls for the respect of an ethics in the realm of advertising translation so that culture is not reduced to mere commodities and the translator to a "trader in dreams."

A short glossary of the terminology of translation is appended at the end of the volume, together with a selective index of the most significant notions of the study. The appendices are interesting to consult because they make it possible to measure the extent of the phenomenon of advertising translation and they provide examples of advertisements in other languages than those treated in the body of the work (German, Korean, Polish, etc.).

Throughout the study the presentation is very clear, the analyses are shrewd, and the explanations provided by M. Guidère convincing. The clarity of the argument makes it possible to grasp the originality of the approach. On the basis of the report that the traditional practices (literal, interpretative translation) do not meet the requirements of the nature or the aims of advertising communication the author points to the need for a change of point of view and method. The question is no longer about translating the "letter" of the text, nor even its "meaning," but strictly its "effect" on the receiver. To do so, and as a semiotician, M. Guidère sets off on the search for the verbal and non-verbal signs which carry what he calls the "language praxis" which, to his mind, constitutes the true unit of translation in this type of communication. The study thus leads to the highlighting of certain interlinguistic equivalences between "efficient structures."

Yet the reader is left dissatisfied, so to speak. Admittedly, the author deconstructs the mechanisms of adaptation and the strategies of translation implemented by the multinationals to conquer new markets; admittedly, he prepares the ground for a speculation on the science of translation based on the semiotics of action and manipulation ${ }^{7}$ but a major question remains unanswered: how to evaluate the effectiveness of a translation? The author only gives a partial answer; he eliminates the question from his field of speculation, considering that it does not concern the translator. It seems to us that there is here matter for discussion: If the increase in sales is the only criterion to evaluate the effectiveness of a translation, then how much leeway is given to the translator?

By analysing the practice of professionals engaged in this type of communication, the author shows the limits of a purely theoretical approach to the problems which arise for the advertising translator in the current economic situation. He upsets many received ideas and invites us to view the essential problematics of the science of translation under a new light: first of all concerning the role of the translator who, in this case, stands from now on exclusively on the side of the transmitter, and no longer on the side of the receiver who is manipulated by him; furthermore concerning the nature of the statement to be translated, which is no longer defined in reference to its purport but to its purpose; finally concerning the place of culture which is no longer regarded as an obstacle to the transfer, but rather as a "sale argument," a fact which alters its status and its treatment as far as its translation is concerned.

By doing this, the author does not adopt a strictly contrastive approach; he proceeds, beyond this, with the comparison and confrontation of cases between the 
various languages which he summons to back his analyses. In the majority of cases, these comparisons concern the relevant facts for a compared semiotics in advertising translation, but they leave aside certain aspects which experts would deem central within the framework of a cognitive or psycho-analytical approach. ${ }^{8}$ Here and there, however, many remarks of a general scope make it possible to put into perspective the detailed analyses of the selected corpus. It is, above all, the third part of the book which re-examines and widens the problematics treated in a more "technical" way in the main body of the study. However, one may regret the fact that occasionally the argument is satisfied with giving general orientations concerning the essential phenomena of advertising translation: for example the lexical and ideological transfers in the sub-divisions "Lexiculture" (III.2.1) and "Ideoculture" (III.2.2).

However, the explanations, which are very well carried out, make it possible to grasp the mechanisms of adaptation in the selected languages. Moreover, M. Guidère excels in the highlighting of the subtle differences in meaning between the multiple advertising versions. Thus, to quote only one example, he gives an exacting analysis of the advertisement for Tissot watches, emphasizing the strong points and the weaknesses of the various existing translations of the original message (pp. 149-154).

The multiple illustrative examples which punctuate the text, and which make it possible to check the validity of the analysis carried out, are borrowed from a variety of languages, in particular Arabic, a rare enough fact to deserve a mention ${ }^{9}$. Anxious to give a faithful image of translating practice in the field of international communication, M. Guidère transcribes advertisements concerned with various fields, with a predilection for promotional advertisements for luxury products (advertisements for perfumes, cosmetics, watches etc.). These advertisements are all post-1995 which confirms the topicality of the study and the novelty of the problematics.

All things considered, the work is of tremendous interest and presents a high level of specialization. One might regret, however, the absence, in the bibliography, of any reference to the writings falling under the "skopos theory." ${ }^{10}$ Nonetheless, the rigorousness of the analysis and the overall consistency produce here a work of great quality, in a class of its own and bound to promote a field of research neglected up to now.

Francis Guinle

Université Lumière Lyon 2, Lyon, France

\section{NOTES}

1. Cf. U. Gruber (1987), «La communication internationale a sa langue: l'adaptation,» dans Revue française du Marketing, $\mathrm{n}^{\circ} 114$, pp. 59-64.

2. See advertisements pp. 285-298.

3. See pp. 64-80.

4. See analysis pp. 184-214.

5. See pp. 231-244, and J.M. Floch (1995), Identités visuelles, Paris: P.U.F., 185 p.

6. Cf. J.E. Donnely (1970), «Attitudes Toward Culture and Approach to International Advertising», in Journal of Marketing, vol. 34, pp. 18-35.

7. Cf. N. Evereart-Desmet (1984), La communication publicitaire: étude sémio-pragmatique, Louvainla-Neuve, Cabay, 310 p.

8. Cf. D. Seleskovitch (1978), «Language and Cognition», in Gerver and Sinaiko (eds), pp. 38-82.

9. The author is a specialist of this language which he teaches at the Université Lumière-Lyon2.

10. For example, H.J. Vermeer (1989), Skopos und translationsauftrag - Aufsatze (Translatorisches Handeln, Wissenschaft 2) Frankfurt: IKO, 160 pp. 


\section{REFERENCES}

Boivineau, R. (1972): «L'abc de l'adaptation publicitaire,» dans Meta, 17-1, numéro spécial.

Cordonnier, J.-L. (1995): Traduction et culture, Paris: Hatier, 285 pp.

De Pedro, R. (1996): “Beyond the Words: The Translation of Television Adverts," in Babel, 42, $n^{\circ}$ 1, pp. 27-45.

Hönig, H. und P. Kussmaul (1982): Strategie der Übersetzung, Tübingen: Narr, 226 pp.

Mounin, G. (1994, nouv. éd.): Les Belles Infidèles, Lille: Presses universitaires de Lille, 190 pp.

TAtilon, C. (1990), «Le texte publicitaire: traduction ou adaptation?,» dans Meta, 35-1, pp. $243-$ 246.

Krings, Hans P. (2001): Repairing Texts: Empirical Investigations of Machine Translation Post-Editing Processes (Geoffrey S. Koby, ed.), The Kent State University Press, Kent, Ohio \& London, 558 p.

This substantial volume is a skillful English rendering of Hans Krings' postdoctoral (Habilitation) thesis of 1994 published in German under the title Texte Reparieren. The thesis project was an extensive experimental study of the mental processes used in machine translation (MT) post-editing, employing the Think-Aloud Protocol (TAP). Post-editing is generally taken as the human process of first comparing a source text with the raw output of an MT system, then making changes in the output language text to meet some criteria of suitability for a specified purpose. Krings takes a psycholinguistic view of the problem of comparing MT plus post-editing to conventional human translation (which often involves revision). While not neglecting the current (and presumably future) limitations of MT systems, he accepts the utility and even the necessity of post-edited MT, especially in commercial situations. He tries to measure the economic costs, effort and various cognitive factors involved in various post-editing situations, all with an aim to formulate hypotheses for future study. In the many of the experiments, post-editors have given real-time comments on their translation tasks in progress, then provided additional remarks after task completion while listening to their in-progress comments. Various post-editing operations are examined in detail, and some of the experiments limit the posteditor's access to the source text. Despite the hesitation to make premature generalizations, there are many interesting conjectures here, and plenty of data to help MT users decide how to use post-editing effectively.

The experiments were carried out on several multilingual instructional texts, with MT provided between German, English and French by two MT systems: SYSTRAN and METAL. Four lengthy discussion chapters on data analysis, totalling over 300 pages, provide specific examples, and include numerous tables summarizing the experimental results. A 24-page appendix gives the experimental texts in their entirety, along with raw MT output from the two systems.

The book's editor, Geoffrey Koby has provided an excellent introduction, which serves not only to update the field of computer-assisted translation and put the work in a broader perspective, but also to summarize and critique some of the results and conclusions. Koby points out that the post-editing in the study was carried out with pencil on paper printout for reasons of methodological uniformity a decade ago, when word-processing tools and skills were much less widespread. While most of the 